\title{
A diverse snake fauna from the early Eocene of Vastan Lignite Mine, Gujarat, India
}

Jean-Claude Rage, Annelise Folie, Rajendra S. Rana, Hukam Singh, Kenneth D. Rose, and Thierry Smith

Acta Palaeontologica Polonica 53 (3), 2008: 391-403 doi:http://dx.doi.org/10.4202/app.2008.0303

The early Eocene (Ypresian) Cambay Formation of Vastan Lignite Mine in Gujarat, western India, has produced a diverse assemblage of snakes including at least ten species that belong to the Madtsoiidae, Palaeophiidae (Palaeophis and Pterosphenus), Boidae, and several Caenophidia. Within the latter taxon, the Colubroidea are represented by Russellophis crassus sp. nov. (Russellophiidae) and by Procerophis sahnii gen. et sp. nov. Thaumastophis missiaeni gen. et sp. nov. is a caenophidian of uncertain family assignment. At least two other forms probably represent new genera and species, but they are not named; both appear to be related to the Caenophidia. The number of taxa that represent the Colubroidea or at least the Caenophidia, i.e., advanced snakes, is astonishing for the Eocene. This is consistent with the view that Asia played an important part in the early history of these taxa. The fossils come from marine and continental levels; however, no significant difference is evident between faunas from these levels. The fauna from Vastan Mine includes highly aquatic, amphibious, and terrestrial snakes. All are found in the continental levels, including the aquatic palaeophiids, whereas the marine beds yielded only two taxa. Vastan Mine is only the second locality in which the palaeophiids Palaeophis and Pterosphenus co-occur. The composition of the fauna from Vastan is on the whole similar to that of the early Eocene of Europe; however, comparisons with early Eocene faunas of other continents are not possible because they are poorly known or unknown.

Key words: Serpentes, Caenophidia, Eocene, Vastan, India

Jean-Claude Rage [jcrage@mnhn.fr], Muséum national d'Histoire naturelle, UMR 5143 CNRS, CP 38, 8 rue Buffon, 75231 Paris cedex

05, France; Annelise Folie [annelise.folie@naturalsciences.be] and Thierry Smith [thierry.smith@naturalsciences.be], Royal Belgian Institute of Natural Sciences, Department of Paleontology, Rue Vautier 29, B-1000 Brussels, Belgium; Rajendra S. Rana [rs_rana_hnbgu@yahoo.com], Department of Geology, H.N.B. Garhwal University, Srinagar 246175, Uttaranchal, India; Hukam Singh [hukams@gmail.com], Birbal Sahni Institute of Palaeobotany, 53 University Road, Lucknow-226007, U.P., India; Kenneth D. Rose [kdrose@ jhmi.edu], Center for Functional Anatomy and Evolution, Johns Hopkins University School of Medicine, Baltimore, Maryland 21205, 
USA.

This is an open-access article distributed under the terms of the Creative Commons Attribution License (for details please see creativecommons.org), which permits unrestricted use, distribution, and reproduction in any medium, provided the original author and source are credited.

Farif Full text $(743.1 \mathrm{kB})$ 